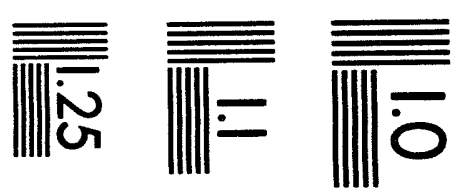

$$
\begin{aligned}
& \text { If }
\end{aligned}
$$

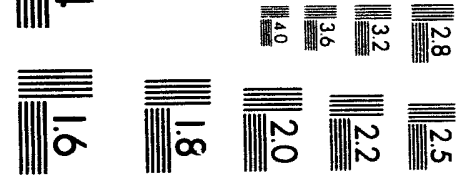



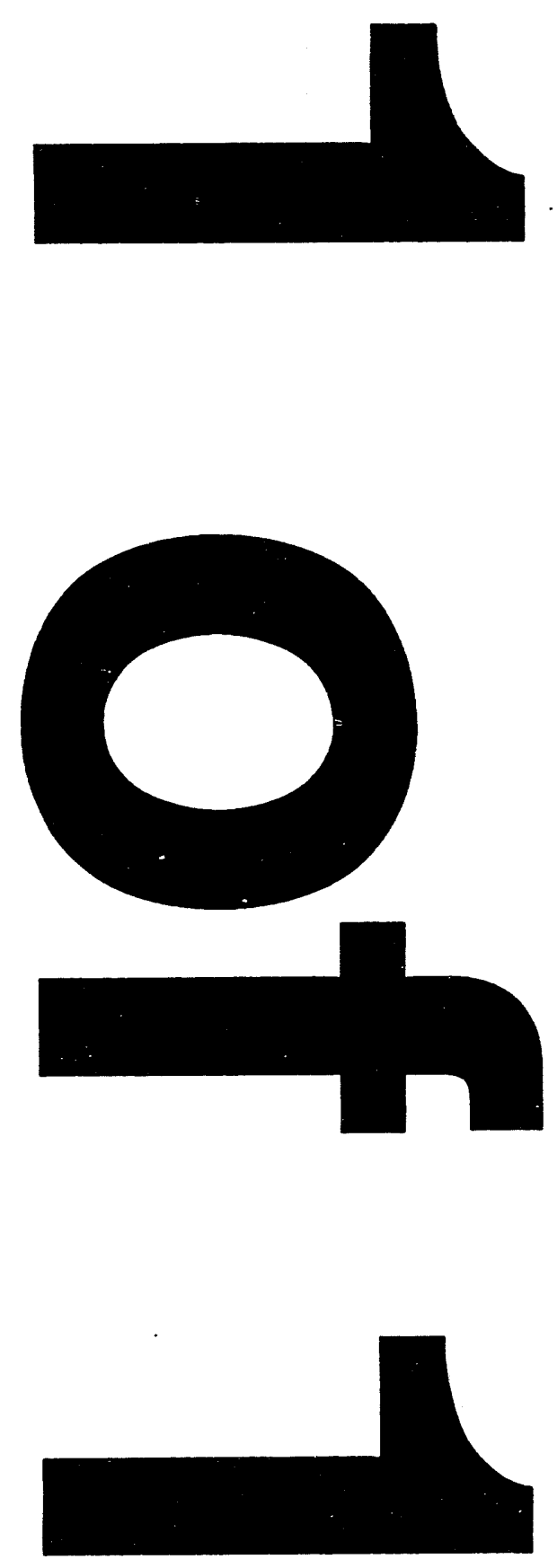
NUREG/CR-6080

ANL-93/19

9C, 9D, GF

\section{Replacement Energy, Capacity, and Reliability Costs for Permanent Nuclear Reactor Shutdowns}

Manuscript Completed: July 1993

Date Published: October 1993

Prepared by

J. C. VanKuiken, W. A. Buchring, S. Hamilton, J. A. Kavicky,

J. D. Cavallo, 'T. D. Veselka, D. L. Willing

Argonne National Laboratory

$9700 \mathrm{~S}$. Cass Avenue

Argonne, IL 60439

Prepared for

Division of Regulatory Applications

Office of Nuclear Regulatory Research

U.S. Nuclear Regulatory Commission

Washington, DC 20555-0001

NRC FIN A2199 


\begin{abstract}
Average replacement power costs are estimated for potential permanent shutdowns of nuclear electricity-generating units. Replacement power costs are considered to include replacement energy, capacity, and reliability cost components. These estimates were developed to assist the U.S. Nuclear Regulatory Commission in evaluating regulatory issues that potentially affect changes in serious reactor accident frequencies. Cost estimates were derived from long-term production-cost and capacity expansion simulations of pooled utilitysystem operations. Factors that affect replacement power cost, such as load growth, replacement sources of generation, and capital costs for replacement capacity, were treated in the analysis. Costs are presented for a representative reactor and for selected subcategories of reactors, based on estimates for 112 individual reactors.
\end{abstract}




\section{CONTENTS}

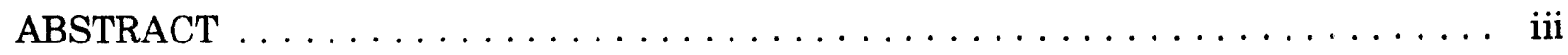

ACKNOWLEDGMENTS $\ldots \ldots \ldots \ldots \ldots \ldots \ldots \ldots \ldots \ldots \ldots \ldots \ldots$ vii

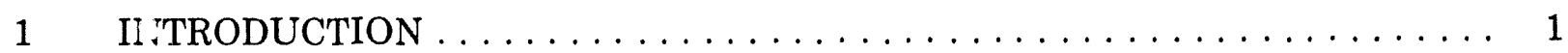

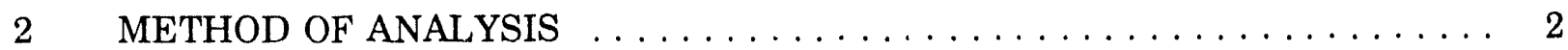

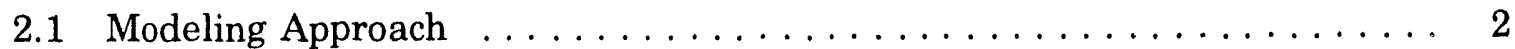

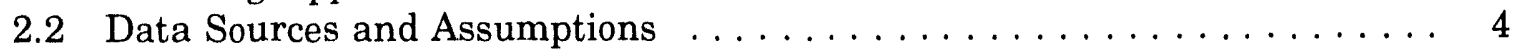

2.3 Derivation of Average Replacement Power Costs ............ 5

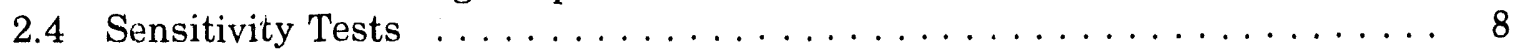

$3 \quad \operatorname{RESULTS} \ldots \ldots \ldots \ldots \ldots \ldots \ldots \ldots \ldots \ldots \ldots \ldots \ldots$

3.1 Cost Estimates for Regulatory Actions Introduced in $1993 \ldots \ldots \ldots \ldots$. . . . 11

3.2 Cost Estimates for Regulatory Actions Introduced in Future Years . . . . . 12

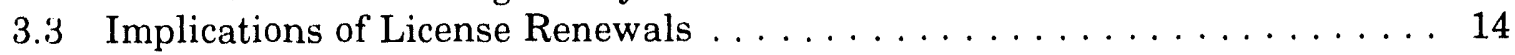

3.4 Application of Results $\ldots \ldots \ldots \ldots \ldots \ldots \ldots \ldots \ldots \ldots \ldots \ldots$

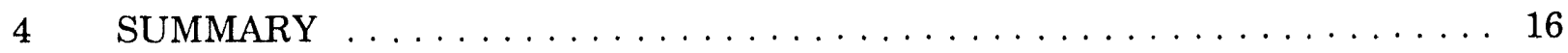

REFERENCES $\ldots \ldots \ldots \ldots \ldots \ldots \ldots \ldots \ldots \ldots \ldots \ldots \ldots$

APPENDIX: Replacement Power Costs by Reactor Subcategory . . . . . . . . 18

\section{FIGURE}

3.1 Average Replacement Power Cost for Regulatory Actions Introduced

in Future Years . . . . . . . . . . . . . . . . . . . . .

\section{TABLES}

2.1 Annual Cost Increases for a Hypothetical Shutdown of Limerick 1 in 1993.

2.2 Annual Cost Results for a Hypothetical Shutdown of Limerick 1

Beginning in 1993 to 2024

3.1 Total and Average Costs for Regulatory Actions Introduced in 1993. 


\section{TABLES (Cont.)}

3.2 Average Replacement Power Costs for Regulatory Actions Introduced from 1993 to $2002 \ldots \ldots \ldots \ldots \ldots \ldots \ldots \ldots \ldots \ldots \ldots$

A.1 Average Replacement Power Cost for All Reactors in This Study, 1993 and $2003 \ldots \ldots \ldots \ldots \ldots \ldots$

A.2 Average Replacement Power Cost for Boiling and Pressurized-Water Reactors, 1993 and 2003 . . . . . . . . . . . . . . . . . . . . . . . . . . . . 19

A.3 Average Replacement Power Cost for Reactors by Size,

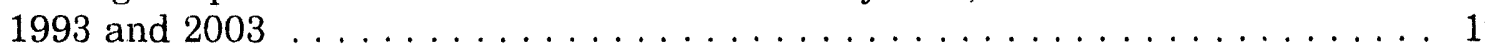

A.4 Average Replacement Power Cost of Reactors by Remaining

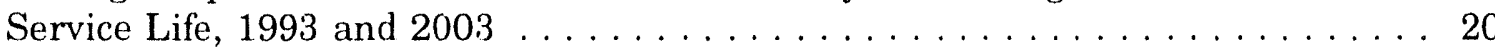

A.5 Average Replacement Power Cost for Reactors by Utility, 1993 and 2003

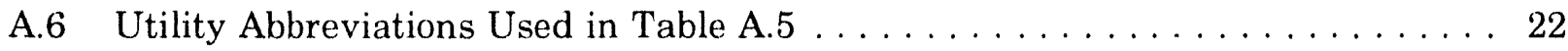

A.7 Average Replacement Power Cost by Nuclear Steam System

Suppliers and Design Types, 1993 and 2003

A.8 Average Replacement Power Cost for Reactors by Turbine

Generator Suppliers, 1993 and 2003.

A.9 Average Replacement Power Cost for Reactors by Architect

Engineers, 1993 and 2003

A.10 Average Replacement Power Cost for Reactors by Constructors, 1993 and 2003 


\section{ACKNOWLEDGMENTS}

The authors would like to express their appreciation to the following individuals who have contributed significantly to this report. Sidney Feld, U.S. Nuclear Regulatory Commission, provided valuable direction and insights to the analysis. Special thanks go to Argonne National Laboratory's Information and Publishing Division for providing editorial (Margaret Clemmons) and word processing (Document Processing Center) support. 


\section{FOREWORD}

This report provides the Nuclear Regulatory Commission with a capability to evaluate long-term replacement power costs including investigations into key sensitivities affecting these costs. These cost estimates were developed to assist in evaluating regulatory issues that potentially affect changes in serious reactor accident frequencies.

NUREG/CR-6080 is not a substitute for U.S. Nuclear Regulatory Commission (NRC) regulations, and compliance is not required. The approaches and/or methods described in this NUREG are provided for information only. Publication of this report does not necessarily constitute NRC approval or agreement with the information contained herein. 


\title{
REPLACEMENT ENERGY, CAPACITY, AND RELIABILITY COSTS FOR PERMANENT NUCLEAR REACTOR SHUTDOWNS
}

\author{
by \\ J.C. VanKuiken, W.A. Buehring, S. Hamilton, J.A. Kavicky, \\ J.D. Cavallo, T.D. Veselka, and D.L. Willing
}

\section{INTRODUCTION}

This report gives estimates of average utility-related costs associated with the permanent loss of a nuclear reactor. These costs represent replacement costs for the energy and capacity supplied by nuclear electricity-generating units in the event of a serious accident or reactor failure that precludes returning the reactor to service. In addition to energy and capacity cost components, this report also gives estimates of the costs associated with reduced generating system reliability. This analysis does not address other categories of costs (e.g., those costs associated with decommissioning, cleanup and decontamination, or public health and safety).

These results were developed for use by the U.S. Nuclear Regulatory Commission in estimating the value of alternative regulatory actions that affect the probabilities of serious reactor accidents. Replacement power costs reflect the averagie integrated value associated with the loss of a representative reactor thot could occur in any year of a reactor's remaining operating life. This representation allou's the analyst to multiply the costs by the number of operating reactors and the expected change in probability of reactor losses to determine the value of a regulatory action.

All costs expressed in this report are given in terms of the net present value in mid1993 dollars, assuming a $7 \%$ real discount rate. The analyst should carefully review the description of how the costs are derived, along with the example provided in this report, before applying the cost estimates to expected changes in reactor-loss probabilities.

The costs represent an average for the 112 U.S. reactors currently operating or expected to begin operations by 1996 . These reactors were analyzed in VanKuiken et al. (1992) to determine the replacement energy costs of short-term (one year or less) shutdowns during the five-year study period (1992-1996). The estimates in the present report extend the previous analysis to consider long-term shutdowns that would last tho remaining lifotime of a given reactor. The appendix includes cost estimates for alternative groupings of reactors; costs are given, for example, by type, unit size, and utility. 


\section{METHOD OF ANALYSIS}

In the event of a permanent shutdown, it is assumed that a reactor would be replaced by one or more alternative generating units after an appropriate delay for planning and construction. In the present study, the ARGonne Utility Simulation (ARGUS) model (Veselka et al. 1990) was used to estimate the sequence of adding new replacement capacity during a 40-year study period (1993-2032). ${ }^{1}$ Results from these simulations were used to determine the fixed and variable costs associated with replacing nuclear generation and capacity at an equivalent level of system reliability.

ARGUS is a dynamic programming model that selects the least-cost sequence of adding new generating capacity to replace retiring units and to meet future growth in system demands. It includes the same detailed production-cost modeling algorithm (Guziel et al. 1990) used previously to estimate short-term replacement energy costs. ${ }^{2}$ New capacity additions are selected from a list of user-defined expansion candidates.

To limit the number of ARGUS simulations required to complete the analysis, six representative power pools ${ }^{3}$ and reactors were selected for initial analysis. The findings were used to approximate costs for the other 106 reactors by scaling the results for reactor unit sizes, relative replacement energy costs, and remaining service lifetimes. Power pool selections were based on two objectives: (1) to include pools with the greatest number of nuclear units and (2) to span the range of short-term replacement energy costs. The six power pools chosen for simulations contain 66 of the 112 reactors to be evaluated and include replacement energy costs ranging from 12 to $30 \mathrm{mill} / \mathrm{kWh}$.

\subsection{MODELING APPROACH}

Two 40-year simulations were required for each of the representative power pools - one simulation with a designated reactor in service and one with the reactor removed from service beginning in 1993. In all cases, a 15\% target reserve margin was adopted to determine the timing and magnitude of new capacity requirements. A minimum delay of 8 years was imposed for planning and construction of new capacity in the shutdown cases.

The net costs for energy, capacity, and reliability were determined from the differences between the pairs of simulations. Costs were also estimated for reactor losses

1 The 40-year time frame encompasses the remaining licensed lifetimes for existing reactors. Implications for license renewal periods of an additional 20 years are discussed in Section 3.

2 The production-cost model is the Investigation of Costs and Reliability in Utility Systems (ICARUS) model. This model uses detailed unit-by-unit system representations, with explicit recognition of random unit failure probabilities, to obtain realistic estimates of system costs and reliability.

3 Power pools represent groups of utilities with coordinated planning and/or operating agreements. 
beginning in 1994 and continuing on an annual basis throughout the remaining licensed operating periods.

These simulations provided the basis for estimating replacement power costs for all 112 reactors. For reactors located in one of the six simulated power pools (66 reactors), the outcomes only had to be scaled according to unit size and remaining operating life. For reactors in other power pools, the energy component of replacement power costs was also adjusted to reflect the differences in short-term replacement energy costs. VanKuiken et al. (1992) was used to determine the appropriate scaling factors for this calculation.

The objective of this analysis was to estimate the average integrated value for the loss of a representative reactor that could occur in any year of a reactor's remaining operating life. This estimate allows the analyst to multiply the costs by the expected change in probability of reactor losses and number of reactors affected to determine the averted replacement power cost associated with a regulatory action. Equation 1 illustrates the intended use of the cost estimates:

$$
V=N \Delta F U,
$$

where

$$
\begin{aligned}
V & =\text { net present value of averted replacement power cost }{ }^{4}(\$), \\
N & =\text { number of affected reactor facilities, } \\
\Delta F & =\text { reduction in accident frequency (probability of loss/reactor-yr), and } \\
U & =\text { present value of replacement power costs over life of facility }(\$-y r) .
\end{aligned}
$$

To estimate a representative value for $U$, reactor-specific lifetime costs for potential shutdowns beginning in 1993 were summed over all reactors operating in 1993 . The process was repeated for reactor losses that could occur beginning in 1994 and on an annual basis through 2032. Overall totals and averages were developed by summing the costs for all beginning years of reactor losses and dividing by the total number of reactors (112 reactors operating during or after 1993). This calculation yields average costs for losses that could

4 The term "replacement power cost" is used in this report to refer to replacement energy, capacity, and reliability cost components of reactor shutdown costs. It does not include other categories of costs for potential accidents such as decommissioning, cleanup and decontamination, or public health and safety. 
occur in any year of operations beginning with $1993 .^{5}$ The average replacement power cost $(U)$ can be multiplied by a change in accident frequency $(\Delta F)$ and the number of reactors affected $(N)$ to yield the averted cost of regulatory actions ( $V$ ).

As a final step, the entire process was repeated to determine averted costs attributed to future regulatory actions. Future regulatory actions were assumed to affect reoctor-loss probabilities and costs beginning with the year the action is implemented. Costs for fulur: actions are expressed in 1993 dollars, present valued to the year of implementation.

\subsection{DATA SOURCES AND ASSUMPTIONS}

For this study, candidate technologies for capacity expansion and replacement were developed on the basis of guidance from the announced utility plans for additions over the next 10 years (North American Reliability Council 1991). Three to four candidates were established for each pool; these candidates reflected the unit sizes, technology types, and fuel types observed in the announced plans. The options typically included a natural gas combustion turbine, a natural gas combined-cycle facility, and a coal-fueled steam generator with flue-gas desulfurization.

Annual demand growth forecasts were developed at Argonne National Laboratory through the use of econometric models for customer classes (i.e., residential, commercial, industrial, and other) in each of the selected power pools. Data sources included U.S. Department of Energy (DOE) Energy Information Administration (EIA) energy sales and price information at the state level (DOE 1983-1990), weather data (Bair 1992), and population and personal income data (U.S. Department of Commerce 1975-1990). The forecasts for independent variables were derived from current Data kesources Incorporated (1992) forecasts of energy prices, population, and personal income. This approach yielded growth rates of approximately $1.5 \%$ per year, with some variation between power pools and years of the study.

Fuel costs for fossil-fired electric generating units are based on historical fuel prices and fuel escalation rates. Initial 1993 fuel costs are based on estimates developed for VanKuiken et al. (1992), with adjustments to reflect 1993 dollars. Fuel prices after 1993 are estimated by applying fuel escalation growth rates to the base-year price. Growth rates through the year 2010) are based on EIA regional estimates (DOE 1992). Fuel prices for the low demand growth scenario were selected from the EIA study to be consistent with the demand growth rates used in this analysis.

5 Because the probability of reactor loss is assumed to be very low (e.g., on the order of $10^{-5}$ event/reactor-yr), costs for alternative shutdown events can be summed and averaged as if the events were independent. That is, the effects of dependent outage probabilities (e.g., a permanent reactor shutdown that begins in 1993 precludes a loss for the same reactor beginning in 1994) are negligible. 
Fuei price escalation rates after 2010 for oil-derived products and natural gas are based on a study performed by EIA in support of the National Energy Strategy (DOE 1991). Because these price projections are at the national level, the same growth rates were used for all power pools. Coal prices were held constant in real terms after 2010 on the basis of available projections.

\subsection{DERIVATION OF AVERAGE REPLACEMENT POWER COSTS (SINGLE REACTOR EXAMPLE)}

The following example illustrates several intermediate steps required in the derivation of integrated replacement power costs. Table 2.1 displays the annual cost results for a hypothetical shutdown of Limerick 1 (one of the six designated reactors) beginning in 1993. All costs in Table 2.1 are expressed in 1993 dollars, and all discounted values assume a real discount rate of $7 \%$.

The table projects cost increases to 2024, the last year Limeri $\mathrm{k} 1$ is currently licensed to operate. The original simulations treated Limerick 1 as operational through 2032, so that the results could be used to estimate costs for other reactors whose licensed operating periods extended beyond 2024. Once the initial data were established, costs were truncated at the end of each reactor-specific licensing period.

Table 2.1 displays cost components in three categories: energy, capacity, and reliability. Costs in all three of these categories represent the net differences between a simulation with the reactor in service and a case with the unit shut down in 1993. Energy costs include fuel costs, variable operation and maintenance (O\&M) costs, and fixed O\&M costs for all replacement energy from generating units in the same pool as the shutdown reactor. ${ }^{6}$ Capacity costs include the annual levelized fixed capital costs for new capacity additions (assuming a capital recovery factor of $8.06 \%$ per year). ${ }^{7}$ Reliability costs include costs for emergency capacity and energy purchases. "Reliability" includes all energy purchases from neighboring power pools, even though these exchanges typically would not create a true "emergency" to deliver. Reliability costs reflect the fixed and variable costs for purchases at rates that are representative of combustion turbines (approximately $\$ 400 / \mathrm{kW}$ and $90 \mathrm{mill} / \mathrm{kWh}$, respectively).

6 Net fixed O\&M costs (reactor-out case minus reactor-in case) are typically negative (representing a net cost decrease) because of the high cost for nuclear units. This analysis relied on estimates developer for VanKuiken et al. (1992), which assumed that fixed O\&M cost.s for nuclear units were approximately $\$ 90 / \mathrm{kW}$-yr. Costs for replacement coal-fired capacity are typically on the order of $\$ 40 / \mathrm{kW}-\mathrm{yr}$.

7 Capacity costs are shown as zero for the first 14 years because the system reserve margin for these years is greater than the $15 \%$ reserve criteria adopted for this analysis. At the same time, energy and reliability costs increase during this initial time period. Higher priced generating units are called on to provide larger amourts of replacement energy, and system reliability declines relative to the base case as loads increase over time. For most of the other power pools, capacity costs begin to occur as soon as the 8 -year delay for planning and construction conds. 
TABLE 2.1 Annual Cost Increases for a Hypothetical Shutdown of Limerick 1 in $1993\left(1,055-M W\right.$ unit, license expires in 2024) $\left(1993 \$ 10^{6}\right)$

\begin{tabular}{|c|c|c|c|c|c|c|c|c|}
\hline Year & $\begin{array}{l}\text { Dsc } \\
\text { Fac }\end{array}$ & Energy & $\begin{array}{l}\text { Dsc'd } \\
\text { Energy }\end{array}$ & Capacity & $\begin{array}{l}\text { Dsc'd } \\
\text { Cap. }\end{array}$ & Rel. & $\begin{array}{l}\text { Dscid } \\
\text { Rel. }\end{array}$ & $\begin{array}{l}\text { Dsc'd } \\
\text { Total }\end{array}$ \\
\hline 1993 & 1.0000 & 34.3 & 343 & 0.0 & 0.0 & $\overline{31.4}$ & 31.4 & 65.7 \\
\hline 1994 & 0.9346 & 34.3 & 32.1 & 0.0 & 0.0 & 31.4 & 29.3 & 61.4 \\
\hline 1995 & 0.8735 & 30.6 & 26.7 & 0.0 & 0.0 & 31.6 & 27.6 & 543 \\
\hline 1996 & 0.8164 & 30.6 & 25.0 & 0.0 & 0.0 & 31.6 & 25.8 & $\overline{50.8}$ \\
\hline 1997 & 0.7630 & 41.3 & 31.5 & 0.0 & 0.0 & 33.9 & 25.9 & 57.4 \\
\hline 1998 & 0.7131 & 41.3 & 29.5 & 0.0 & 0.0 & 33.9 & 24.2 & 53.7 \\
\hline 1999 & 0.6664 & 52.8 & 35.2 & 0.0 & 0.0 & 34.2 & 22.8 & 58.0 \\
\hline 2000 & 0.6228 & 52.8 & 32.9 & 0.0 & 0.0 & 34.2 & $\overline{21.3}$ & 54.2 \\
\hline 2001 & 0.5821 & 70.9 & 41.3 & 0.0 & 0.0 & 36.2 & 21.1 & $\overline{62.4}$ \\
\hline 2002 & 0.5440 & 70.9 & 38.6 & 0.0 & 0.0 & 36.2 & 19.7 & 58.3 \\
\hline 2003 & 0.5084 & 89.2 & 45.3 & 0.0 & 0.0 & 41.6 & 21.1 & 66.4 \\
\hline 2004 & 0.4751 & 89.2 & 42.4 & 0.0 & 0.0 & 41.6 & 19.8 & 52.2 \\
\hline 2005 & 0.4440 & 118.0 & 52.4 & 0.0 & 0.0 & 51.5 & 22.9 & 75.3 \\
\hline 2006 & 0.4150 & 118.0 & 49.0 & 0.3 & 0.0 & 51.5 & 21.4 & 70.4 \\
\hline 2007 & 0.3879 & 66.4 & 25.8 & 110.9 & 43.0 & 5.7 & 2.2 & 71.0 \\
\hline 2008 & 0.3625 & 664 & 24.1 & 110.9 & 40.2 & 5.7 & 2.1 & 66.4 \\
\hline 2009 & 0.3388 & $27 . \overline{3}$ & 92 & 166.4 & 56.4 & -17.8 & -6.0 & 59.6 \\
\hline 2010 & $0.3: 66$ & 27.3 & 8.6 & 166.4 & 52.7 & -17.8 & -5.6 & 55.7 \\
\hline 2011 & $0 . \overline{2959}$ & 36.0 & 10.7 & 1664 & 49.2 & -17.2 & .5 .1 & 54.8 \\
\hline 2012 & 0.2765 & 36.0 & 100 & 166.4 & 46.0 & -17.2 & -4.8 & 51.2 \\
\hline 2013 & 0.2584 & 32.5 & 8.4 & 166.4 & 43.0 & .166 & -4.3 & 47.1 \\
\hline 2014 & 0.2415 & 32.5 & 7.8 & 166.4 & 402 & .16 .6 & -4.0 & 44.0 \\
\hline 2015 & 0.2257 & 88.1 & 199 & 110.9 & 25.0 & 5.2 & 1.2 & 46.1 \\
\hline 2016 & 0.2109 & 88.1 & 186 & 110.9 & 23.4 & 52 & 1.1 & 43.1 \\
\hline 2017 & 01971 & 78.8 & 15.5 & 110.9 & 21.9 & $\overline{8.1}$ & 1.6 & 39.0 \\
\hline 2018 & 0.1842 & 788 & 14.5 & 110.9 & 20.4 & 8.1 & 1.5 & 36.4 \\
\hline 2019 & $0.17 \overline{721}$ & 29.6 & 5.1 & 166.4 & 28.6 & .15 .2 & -2.6 & 31.1 \\
\hline 2020 & $0 \longdiv { 1 6 0 8 }$ & 296 & 48 & 166.4 & 26.8 & .15 .2 & .2 .4 & 29.2 \\
\hline 2021 & 01503 & 79.2 & 119 & 1109 & 167 & 5.8 & 0.9 & 29.5 \\
\hline 2022 & 01405 & 792 & $1: 1$ & 110.9 & 156 & 5.8 & 0.8 & 27.5 \\
\hline 2023 & 01313 & 258 & 34 & 166.4 & 218 & 14.7 & -1.9 & 233 \\
\hline 2024 & 0.1227 & 258 & 32 & 166.4 & 20.4 & .14 .7 & -1.8 & 21.8 \\
\hline Total & & 18016 & 7288 & $\overline{2.5512}$ & 591.3 & 4074 & 307.2 & $\overline{1,627.3}$ \\
\hline \multirow{2}{*}{\multicolumn{8}{|c|}{ 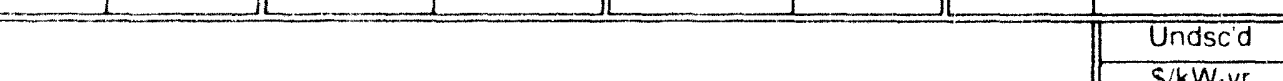 }} & 4.760 .2 \\
\hline & & & & & & & $\$ / k W \cdot y r$ & 48.2 \\
\hline
\end{tabular}

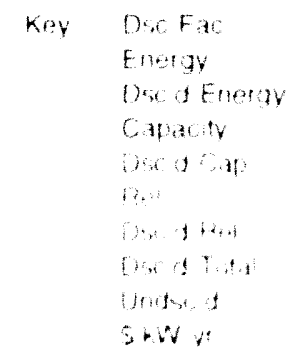

fin $10 .+10$

Dow of Eneray

Capacty

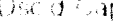

$\int+x^{2}+1+1,4$

Whilose

$5+6 \%$
Discount tactor flaction

heplatament energy cost (mo $1393 \$ 10^{6}$ )

Chachinted tephacement energy cost (mod $1993 \$ 10^{6}$ )

beplacement capactiv cost (mid $1993510^{6}$ )

The ounted capacty cost ind $1993510^{b}$ )

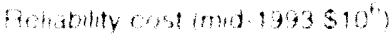

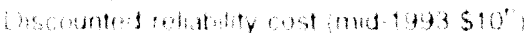

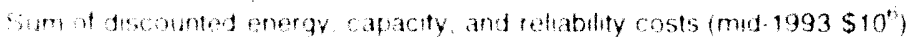

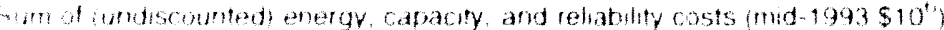

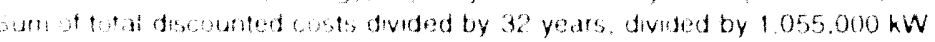


The discount factors ("Dsc Fac") shown in Table 2.1 were used to determine net present value of costs that occur in future years. These discounted costs are shown in the columns labeled "Dsc'd Energy," "Dsc'd Cap.," and "Dsc'd Rel." The sum of all discounted costs is displayed in the column labeled "Dsc'd Total." The bottom rows show the sums of undiscounted and discounted costs and also display the discounted costs in terms of dollars per kilowatt-year.

For Limerick 1, the costs indicate a loss of $\$ 1.6$ billion for a permanent reactor shutdown beginning in 1993 (net present value in 1993 dollars). Energy and capacity contribute approximately $81 \%$ of this total, with the remainder being attributed to reliability costs. For reactors having fewer years of remaining service, the reliability component can be significantly higher. ${ }^{8}$ The total cost can also be expressed as a cost of more than $\$ 48 / \mathrm{kW}$-yr for this reactor.

The next step in deriving integrated costs (i.e., recognizing the potential for outages in future years) was to use data from 1993 shutdown simulations to estimate costs for outage events beginning in 1994 and then on an annual basis through the final year of licensed operation. In order to keep the computational requirements manageable, an estimation procedure was used rather than performing separate simulations. Two approaches were considered; each used the time series of lifetime replacement power costs developed for the 1993 shutdowns. One option deleted costs from the beginning of the time series for years not affected (because of a later date of assumed shutdown). The other option shifted the entire time series later in time (to begin at the year of assumed shutdown) and deleted costs from the end of the time series that extended beyond the reactor lifetime.

That is, to estimate costs for a 1994 loss of Limerick 1 using the second option, the net costs from 1993 to 2024 were assumed to occur from 1994 to 2025 (a 32-year time span), and costs originally incurred during 2024 for the 1993 shutdown were excluded from the 1994 total (a 31-year time span). The result is total costs of $\$ 1.5$ billion (1993 dollars) discounted to 1993. For a 1995 loss, the costs from 1993 to 2024 were assumed to occur over the 1995-2026 time period, and costs originally incurred during 2023 and 2024 were excluded. The result is $\$ 1.4$ billion (1993 dollars) discounted to 1993 for a loss beginning in 1995 .

While the first option maintains consistency between "simulation years" and actual "calendar years," it distorts the contributions from energy, capacity, and reliability cost components. By deleting successive years from the beginning of the time series of costs, this approach, in effect, reduces the time delay required for construction of new capacity. Tests showed that the second approach gave a better representation of the cost profiles for total costs, as well as component costs, that would be expected to occur when time lags for new capacity additions are recognized.

8 Cost results shown in Section 3 show that the reliability component (including contributions from emergency purchases and firm capacity purchases) represent $30 \%-40 \%$ of average shutdown costs for all reactors. 
Table 2.2 shows results from performing the estimating procedure over the remaining operating life of Limerick 1 (1993-2024). The cumulative result for this unit is a total integrated cost of $\$ 16.5$ billion $(\$-y r)^{9}$ discounted to 1993 . This cost represents the value of $U$ in Equation 1, which may be multiplied by $\Delta F$ (probability/reactor-year) to determine the value of averted costs for this single reactor ( $1993 \$$ /reactor). Section 3 provides examples for multiplying by the number of reactors affected to obtain a total cost for all reactors.

The example described above illustrates how the average costs are developed for the six representative reactors. However, to develop more reliable estimates for the entire population of reactors, the raw simulation results were extended to each of the cther 106 reactors. As noted in Section 2.1, results were scaled according to unit sizes, replacement energy costs, and remaining service lifetimes. Finally, costs for all reactors were combined to provide overall totals and averages. The results are summarized in Section 3.

\subsection{SENSITIVITY TESTS}

Several sensitivity tests were conducted to investigate the accuracy of the costestimating procedures. These tests consisted of performing ARGUS simulations of particular shutdown conditions and comparing the results with cost estimates derived by scaling the outcomes from representative unit cases. The specific tests focused on (1) estimating costs for reactors of different sizes and ages in the same power pool as one of the representative reactors and (2) estimating costs for reactors in power pools other than the original six representative systems.

The results from the first test showed close agreement between the simulated outcomes and the estimation procedure. For Dresden 2, a 772-MW unit with license expiring in 2006, simulated costs for a 1993 shutdown were $\$ 768$ million, as compared with $\$ 735$ million derived by scaling results from the 1,036-MW LaSalle 1 reactor (a difference of $4 \%$ ). While this level of precision would not be expected to be achieved in all cases, it is a reasonable indication that errors introduced by scaling results for reactors in the same power pools are relatively minor.

The second test also provided a positive indication of accuracy for applying results from one power pool to reactors in other power pools. For each of the six representative reactors, the ARGUS-simulated results were compared with estimates based on another power pool. For example, the net present value of costs for shutdown of Limerick 1 in 1993 was estimated to be $\$ 1.6$ billion (Table 2.1 ). When the costs were scaled from the costs of shutting down LaSalle 1 , the net present value for Limerick 1 was estimated to be $\$ 1.4$ billion, $13 \%$ lower than the original estimate.

9 The units reported for the final cost estimates are technically $\$$-years because they represent an integral of lifetime replacement power costs summed over all potential years of reactor losses. In practice, however, the integrated costs are often labeled simply in terms of dollars. 
TABLE 2.2 Annual Cost Results for a Hypothetical Shutdown of Limerick 1 Beginning in 1993 to 2024

\begin{tabular}{|c|c|c|}
\hline $\begin{array}{c}\text { Beginning Year } \\
\text { of ihutdown }\end{array}$ & $\begin{array}{l}\text { Total Costs } \\
\qquad\left(\$ 10^{6}\right)\end{array}$ & $\begin{array}{l}\text { Years of } \\
\text { Service } \\
\text { Remaining }\end{array}$ \\
\hline$\overline{993}$ & 1,627 & 32 \\
\hline 1994 & 1,500 & 31 \\
\hline 1995 & $1, \overline{381}$ & 30 \\
\hline 1996 & 1,268 & 29 \\
\hline 1997 & 1,163 & 28 \\
\hline 1998 & 1,066 & 27 \\
\hline $1 \overline{999}$ & $\overline{976}$ & 26 \\
\hline$\overline{2000}$ & $\overline{889}$ & 25 \\
\hline 2001 & 808 & 24 \\
\hline 2002 & $7 \overline{32}$ & 23 \\
\hline 2003 & $\overline{661}$ & 22 \\
\hline 2004 & 597 & 21 \\
\hline 2005 & 537 & $20^{\circ}$ \\
\hline 2006 & 480 & 19 \\
\hline 2007 & 428 & 18 \\
\hline 2008 & 379 & 17 \\
\hline 2009 & 334 & 16 \\
\hline 2010 & 292 & 15 \\
\hline$\overline{2011}$ & 251 & 14 \\
\hline 2012 & 216 & 13 \\
\hline 2013 & 182 & 12 \\
\hline 2014 & 155 & 11 \\
\hline 2015 & 130 & 10 \\
\hline 2016 & 109 & 9 \\
\hline 2017 & 90 & 8 \\
\hline 2018 & 74 & 7 \\
\hline 2019 & 59 & 6 \\
\hline 2020 & 47 & 5 \\
\hline 2021 & 35 & 4 \\
\hline 2022 & 26 & 3 \\
\hline 2023 & 17 & 2 \\
\hline 2024 & 8 & 1 \\
\hline Total & 16,517 & \\
\hline
\end{tabular}


Estimation errors for the six test cases ranged from $-30 \%$ to $+21 \%$ for individual reactors and averaged less than $3 \%$ in the total cost estimates (summed over the six reactors). These results indicate that errors introduced by the extrapolations across different pools provide some offsetting effects and are likely to introduce only moderate impacts on the overall results. This conclusion is further strengthened by the fact that costs for more than one-half of the reactors were estimated from results in the same power pool, which have much tighter error bounds on a reactor-by-reactor basis. 


\section{RESULTS}

This section provides an overview of the cost results and gives two brief examples that illustrate how these results may be applied. As indicated earlier, the cost estimates must be interpreted carefully to avoid misunderstandings. They do not represent the replacement power costs for potential losses in a single year; rather, they are the present value of a stream of costs for possible losses that extend over the remaining reactor lifetimes. In effect, these cost estimates represent a double integration of cost streams because (1) a reacior loss in any given year would lead to replacement power costs for all remaining years of planned operation, and (2) a reactor loss could occur with some small probability in any year of operatir. 1 . The results that follow combine these cost streams for all reactors into average present-value cost estimates.

\subsection{COST ESTIMATES FOR REGULATORY ACTIONS INTRODUCED IN 1993}

Table 3.1 displays the total and average costs for reactor losses for a representative reactor based on the results for all reactors and all of the service years that remain for each reactor. The existing population of 112 reactors has an average unit size of $910-\mathrm{MWe}$ net dependable capacity and an average remaining lifetime of 24 years. The average costs per reactor are obtained by dividing the total costs by the number of reactors (112 reactors in 1993). These costs represent the values that would be affected by regulatory actions introduced in 1993.

The results show an average cost of approximately $\$ 10$ billion ( $\$$-yr) for potential losses that occur from 1993 to 2032 . This average accounts for the years at risk and the years of remaining service during which replacement power costs apply. The reliability component represents about $30 \%$ of the total replacement power costs. Average costs for single-year outage events beginning in 1993 were approximately $\$ 1$ billion. When integrated over the 40-year study period, the single-year costs sum to a present value of $\$ 10$ billion $(\$-y r)$.

As indicated in Section 2.1 , the average cost ( $\$ 10$ billion $\$-y r)$ must be multiplied by the expected change in accident frequency (expressed as a probability per reactor-year) associated with a regulatory action to determine the averted replacement power costs for a "typical" reactor. To determine the combined value for regulatory actions that affect more than a single reactor, the average cost must be multipiied by the change in frequency and the number of reactors affected. Section 3.3 provides examples of such calculations. 
TABLE 3.1 Total and Average Costs for Regulatory Actions Introduced in 1993 (expressed as 1993 present value)

\begin{tabular}{|l|r|r||}
\hline \multicolumn{1}{|c|}{ Cost Category } & $\begin{array}{c}\text { Total Costs Summed } \\
\text { over All Reactors and } \\
\text { All Reactor-Years } \\
\left(\$ 10^{9}\right)^{\mathrm{a}}\end{array}$ & $\begin{array}{c}\text { Average Costs per } \\
\text { Reactor } \\
\left(\$ 10^{9}\right)^{\mathrm{a}}\end{array}$ \\
\hline \hline Capacity and energy & 758 & 6.8 \\
\hline Reliability & 367 & 3.3 \\
\hline Total & 1,126 & 10.1 \\
\hline a Technically, the cost units are \$-years because they represent an \\
integral of lifetime replacement power costs summed over all possible \\
years of reactor losses. However, the more common label $(\$)$ is used \\
here. These costs may be multiplied by the change in probability of \\
reactor loss (per reactor-year) lo give the total dollar savings, as shown \\
in Sections 2.1 and 3.4.
\end{tabular}

\subsection{COST ESTIMATES FOR REGULATORY ACTIONS INTRODUCED IN FUTURE YEARS}

Table 3.2 displays the net present values of regulatory actions introduced during the 10-year period from 1993 to 2002. Costs are expressed in 1993 dollars present-valued to the year in which the action is implemented. ${ }^{10}$ The declining cost pattern primarily shows the effect of reductions in the number of reactor-years for which replacement power costs apply in future years. By 2002, the costs have dropped from $\$ 10$ billion to $\$ 6$ billion. The reliability component represents $41 \%$ of total costs in 2002 .

The increasing percentage of reliability costs can be explained by the higher contribution of "emergency" capacity and energy purchases required during the earlier years of outage events, prior to the construction of replacement capacity. As regulatory actions are assumed to take place later in time, the preconstruction periods become a larger fraction of the total shutdown periods. Figure 3.1 illustrates the long-term trend of total costs over the full 40-year study period. The analyst is cautioned that the number of reactors at risk in a given year of implementation begins to decline after the year 2000 because of expirations of operating licenses.

${ }^{10}$ Because the results in Table 3.2 are discounted to different years, the costs attributed to events in a single year cannot be derived by a simple subtraction of results from two years. For example, the average costs for potential losses beginning only in 1993 would be derived by discounting the 1994 integrated costs by $7 \%$ and subtracting the result from 1993 integrated costs. The result would be $\$ 10$ billion minus $\$ 9$ billion, which yields $\$ 1$ billion for events initiated in 1993 . 
TABLE 3.2 Average Replacement Power Costs for Regulatory Actions Introduced from 1993 to $2002\left(1993 \$ 10^{9}\right.$ present-valued to year of implementation $)$

\begin{tabular}{|l|l|l|l|l|l|l|l|l|l|}
\hline 1993 & 1994 & 1995 & 1996 & 1997 & 1998 & 1999 & 2000 & 2001 & 2002 \\
\hline
\end{tabular}

\begin{tabular}{||c||c|c|c|c|c|c|c|c|c|c|c|}
\hline $\begin{array}{c}\text { Total } \\
\text { summed } \\
\text { costs }\end{array}$ & 1126 & 1070 & 1014 & 958 & 902 & 847 & 792 & 728 & 685 & 632 \\
\hline
\end{tabular}

Costs Averaged over Reactors Remaining in Service

\begin{tabular}{|c|c|c|c|c|c|c|c|c|c|c|}
\hline $\begin{array}{c}\text { Reactors } \\
\text { remaining }\end{array}$ & 112 & 112 & 112 & 112 & 112 & 112 & 112 & 112 & 111 & 111 \\
\hline $\begin{array}{c}\text { Average } \\
\text { costs }\end{array}$ & 10.1 & 9.6 & 9.1 & 8.6 & 8.1 & 7.6 & 7.1 & 6.6 & 6.2 & 5.7 \\
\hline
\end{tabular}

Relative Fractions of Component Cnsts $(\%)$

\begin{tabular}{|c|c|c|c|c|c|c|c|c|c|c|c|}
\hline \hline $\begin{array}{c}\text { Capacity and } \\
\text { energy costs }\end{array}$ & 67 & 67 & 66 & 65 & 64 & 63 & 62 & 61 & 60 & 59 \\
\hline $\begin{array}{c}\text { Reliability } \\
\text { costs }\end{array}$ & 33 & 33 & 34 & 35 & 36 & 37 & 38 & 39 & 40 & 41 \\
\hline
\end{tabular}

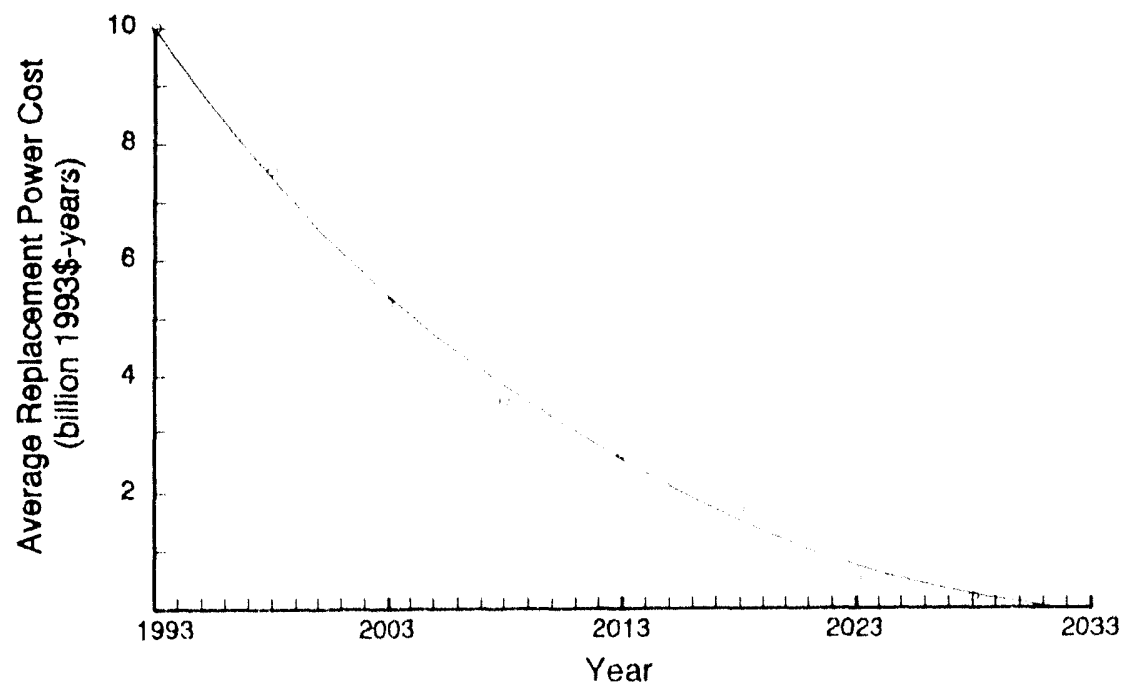

FIGURE 3.1 Average Replacement Power Cost for Regulatory Actions Introduced in Future Years $\left(10^{9} \$-y \mathrm{r}\right)$ 


\subsection{IMPLICATIONS OF LICENSE RENEWALS}

The potential for license renewals or extensions significantly affects estimates for replacement power costs. Tests were made to determine the impact of a 20 -year license renewal period that would extend the licensed operating period from 40 to 60 years for each reactor. This extension would increase the average remaining lifetime from 24 to 44 years for the 112 reactors examined in this study.

Results indicated that average replacement power costs would increase by $90 \%$, from $\$ 10$ billion to $\$ 19$ billion ( $\$$-yr). The increase is substantial, even though additional costs for future years are discounted to a net present value. With a near doubling in the number of years that require replacement power, the average cost for reactor losses initiated in 1993 would increase by more than $30 \%$ in terms of present value. Integrating costs from the single-year events over all years at risk yields the estimate of $\$ 19$ billion averaged over all reactors.

\subsection{APPLICATION OF RESULTS}

The following hypothetical example provides some guidance for estimating the value of regulatory actions from the results of this analysis. The analyst must estimate the change in probability of reactor loss per reactor-year associated with a regulatory action and the number of reactors affected. For example, if the initial probability of reactor loss was assumed to be on the order of $10^{-5}$ per reactor-yr, and a regulatory action was estimated to reduce the risk of loss for all reactors by a factor of $10 \%$, the change in probability would be $10^{-6}$ per reactor-yr.

Example 1:

The replacement energy, capacity, and reliability value of this action introduced in 1993 would be as follows:

$$
\begin{aligned}
\text { Value } & =10^{-6} / \text { reactor-yr } \times 112 \text { reactors } \times 10.1 \times 10^{9} \$-y r \\
& =\$ 1.13 \text { million }(1993 \$ \text { net present value })
\end{aligned}
$$

(Note: The $10.1 \times 10^{9} \$$-yr value was obtained from Table 3.2, under Average Costs for 1993.) 
Example 2:

The value of this same action introduced in 1995 would be as follows:

$$
\begin{aligned}
\text { Value } & =10^{-6} / \text { reactor-yr } \times 112 \text { reactors } \times 9.1 \times 10^{9} \$-\mathrm{yr} \\
& =\$ 1.02 \text { million }(1993 \$ \text { net present-valued to } 1995) .
\end{aligned}
$$

(Note: The $9.1 \times 10^{9} \$$-yr value was obtained from Table 3.2, under Average Costs for 1995.)

These values represent the total present worth for reducing the probability of reactor losses that might have occurred beginning with 1993 in Example 1 and with 1995 in Example 2 and continuing throughout the remaining lifetimes of each reactor. 


\section{SUMMARY}

This analysis investigated the replacement energy, capacity, and reliability costs for permanent reactor shutdowns. These costs were estimated from a series of capacity expansion and production-cost simulations used to estimate costs for all licensed reactors in the United States. Average replacement power costs were estimated for outages that could occur in any given year of reactor operations, beginning with 1993 through the remaining licensed operating periods of each reactor. The average costs are applicable to regulatory actions introduced in 1993 or later during the 40-year study period.

The cost estimates may be multiplied by the change in probability of reactor losses per reactor-year and by the number of reactors that remain to obtain an estimate of the replacement energy, capacity, and reliability value of reducing the risks of reactor accidents. The analyst is urged to review the description of cost derivations to understand fully the scope of this analysis and the limits to applying the results.

The appendix provides additional detail on cost estimates for alternative groupings of reactors (e.g., by type, size, and utility). The average costs by subcategory provide the analyst with information to better evaluate the effect of regulatory actions that might affect distinct subsets of reactors. 


\section{REFERENCES}

Bair, F.E. (editor), 1992, Weather of U.S. Cities, Gale Research, Inc.

Data Resources Incorporated, 1992, Review of the U.S. Economy: Long-Range Forecast, Summer.

DOE, 1983-1990, State Energy Price and Expenditure Report, U.S. Department of Energy, Energy Information Administration, Washington, D.C.

DOE, 1991, National Energy Strategy, SR/NES/90-03, U.S. Department of Energy, Energy Information Administration, Washington, D.C., Jan.

DOE, 1992, Supplement to the Annual Energy Outlook 1992, DOE/EIA-0554(92), U.S. Department of Energy, Energy Information Administration, Washington, D.C., Feb.

Guziel, K.A., J.C. VanKuiken, and W.A. Buehring, 1990, A User's Guide to ICARUS: A Model for Investigating the Cost and Reliability in Utility Systems, ANL/EAIS/TM-19, Argonne National Laboratory, Argonne, Ill., Feb.

North American Reliability Council, 1991, Electricity Supply and Demand 1991-2000, Princeton, N.J., July.

VanKuiken, J.C., et al., 1992, Replacement Energy Costs for Nuclear Electricity Generating Units in the United States: 1992-1996, prepared for the U.S. Nuclear Regulatory Commission, Washington, D.C., by Argonne National Laboratory, Argonne, Ill., NUREG/CR-4012 (ANL-AA-30), Vol. 3.

Veselka, T.D., et al., 1990, Introduction to the Argonne Utility Simulation (ARGUS) Model, ANL/EAIS/TM-10, Argonne National Laboratory, Argonne, Ill., March.

U.S. Department of Commerce, 1975-1990, Statistical Abstract of the United States, Bureau of the Census. 


\section{APPENDIX: \\ REPLACEMENT POWER COSTS BY REACTOR SUBCATEGORY}

This appendix displays the replacement power cost results for alternative groups of reactors. The purpose of these tabulations is to aid the analyst in estimating the potential value of regulatory actions that might affect distinct subsets of reactors in the United States. For example, if a proposed safety regulation affected only boiling water reactors (BWRs), the tables in this appendix could be used to determine the combined value of a reduction in accident frequency for those units.

Section 3.4 in this report illustrates how the replacement power costs can be multiplied by the number of reactors affected and the expected change in accident frequency to estimate the value of a regulatory action. The cost estimates shown in this appendix and in this report address replacement power costs (energy, capacity, and reliability costs), which represent only one component of costs for on-site property damage associated with serious reactor accidents. Other cost components (e.g., decommissioning, cleanup and decontamination, and public health and safety costs) are not included in these estimates.

The results are displayed for potential regulatory implementation in 1993 and for actions taking place 10 years later in 2003. For years between 1993 and 2003 that are not displayed, the analyst can apply linear interpolations with reasonable accuracy (e.g., costs for 1998 would be estimated at one-half the sum of costs for 1993 and 2003). For general guidance on cost trends beyond the 2003 time frame, the average results for all units are graphed in Figure 3.1 through the year 2033.

Nine categories are included for defining subsets of reactors:

- All reactors (for review and comparison),

- Reactor type (BWR or pressurized-water reactor $[P W R]$ ),

- Reactor size,

- Remaining service life,

- Utility,

- Nuclear steam system supplier and design type,

- Turbine generator supplier,

- Architect engineer, and

- Constructor. 
Tables A.1 through A.10 for each category display the numbers of units included in the category, the average size and remaining service life of units in the category, and the average replacement power costs for that group of reactors. The costs are reported in 1993 dollars present-valued to the year the regulatory action is implemented. The tabulated values for average service life remaining assumes a licensed operating life of 40 years. The categories used in the tables in this appendix were determined from Information Digest, 1991 edition, U.S. Nuclear Regulatory Commission, Washington, D.C., NUREG-1350, Vol. 3, March 1991.

TABLE A.1 Average Replacement Power Cost for All Reactors in This Study, 1993 and 2003

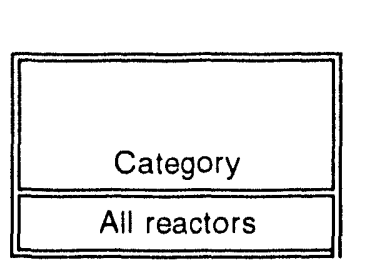

\begin{tabular}{|c|c|c|c|}
\hline Year 1993 \\
\hline \begin{tabular}{c|c} 
Number \\
of Units
\end{tabular} & $\begin{array}{c}\text { Avg. Life } \\
\text { Remaining } \\
(\mathrm{yr})\end{array}$ & $\begin{array}{c}\text { Avg. } \\
\text { Size } \\
(\mathrm{MW})\end{array}$ & $\begin{array}{c}\text { Avg. Repl. } \\
\text { Power Cost } \\
\left(\$ 10^{9}\right)\end{array}$ \\
\hline \hline 112 & 24 & 908 & 10.1 \\
\hline
\end{tabular}

\begin{tabular}{|c|c|c|c|}
\multicolumn{1}{|c|}{ Year 2003} \\
\hline \begin{tabular}{|c|c|c|}
\hline Number \\
of Units
\end{tabular} & $\begin{array}{c}\text { Avg. Life } \\
\text { Remaining } \\
(\mathrm{yr})\end{array}$ & $\begin{array}{c}\text { Avg. } \\
\text { Size } \\
(\mathrm{MW})\end{array}$ & $\begin{array}{c}\text { Avg. Repl. } \\
\text { Power Cost } \\
\left(\$ 10^{9}\right)\end{array}$ \\
\hline 111 & 14 & 915 & 5.2 \\
\hline
\end{tabular}

TABLE A.2 Average Replacement Power Cost for Boiling and Pressurized-Water Reactors, 1993 and 2003

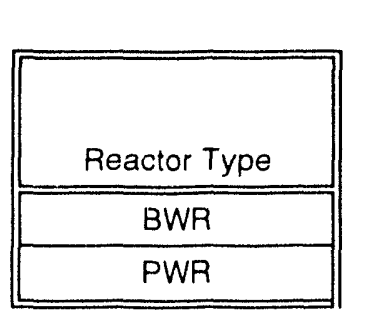

\begin{tabular}{|c|c|c|c|}
\hline \begin{tabular}{|c|c|} 
Year 1993 \\
of Units
\end{tabular} & $\begin{array}{c}\text { Avg. Life } \\
\text { Remaining } \\
(\mathrm{yr})\end{array}$ & $\begin{array}{c}\text { Avg. } \\
\text { Size } \\
(\mathrm{MW})\end{array}$ & $\begin{array}{c}\text { Avg. Repl. } \\
\text { Power Cost } \\
\left(\$ 10^{9}\right)\end{array}$ \\
\hline 36 & 22 & 855 & 7.9 \\
\hline 76 & 24 & 932 & 11.0 \\
\hline
\end{tabular}

\begin{tabular}{|c|c|c|c|}
\hline \multicolumn{1}{|c|}{ Year 2003} \\
\hline $\begin{array}{c}\text { Number } \\
\text { of Units }\end{array}$ & $\begin{array}{c}\text { Avg. Life } \\
\text { Remaining } \\
(\mathrm{yr})\end{array}$ & $\begin{array}{c}\text { Avg. } \\
\text { Size } \\
(\mathrm{MW})\end{array}$ & $\begin{array}{c}\text { Avg. Repl. } \\
\text { Power Cost } \\
\left(\$ 10^{9}\right)\end{array}$ \\
\hline \hline 35 & 13 & 878 & 3.9 \\
\hline 76 & 14 & 932 & 5.9 \\
\hline
\end{tabular}

TABLE A.3 Average Replacement Power Cost for Reactors by Size, 1993 and 2003

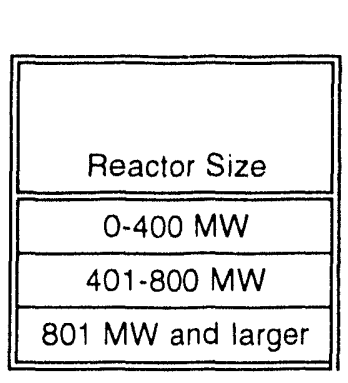

\begin{tabular}{|c|c|c|c|}
\hline $\begin{array}{l}\text { Number } \\
\text { of Units }\end{array}$ & $\begin{array}{c}\text { Avg. Life } \\
\text { Remaining } \\
(y r)\end{array}$ & $\begin{array}{l}\text { Avg. } \\
\text { Size } \\
\text { (MW) }\end{array}$ & $\begin{array}{l}\text { Avg. Repl. } \\
\text { Power Cost } \\
\left(\$ 10^{9}\right)\end{array}$ \\
\hline 1 & 7 & 67 & 0.1 \\
\hline 32 & 17 & 645 & 4.9 \\
\hline 79 & 26 & 1024 & 12.3 \\
\hline
\end{tabular}

\begin{tabular}{||c|c|c|c|}
\hline \hline Year 2003 \\
\hline $\begin{array}{c}\text { Number } \\
\text { of Units }\end{array}$ & $\begin{array}{c}\text { Avg. Life } \\
\text { Aemaining } \\
(\mathrm{yr})\end{array}$ & $\begin{array}{c}\text { Avg. } \\
\text { Size } \\
(\mathrm{MW})\end{array}$ & $\begin{array}{c}\text { Avg. Repl. } \\
\text { Power Cost } \\
\left(\$ 10^{9}\right)\end{array}$ \\
\hline 0 & - & - & - \\
\hline 32 & 7 & 645 & 1.3 \\
\hline 79 & 16 & 1024 & 6.8 \\
\hline
\end{tabular}


TABLE A.4 Average Replacement Power Cost of Reactors by Remaining Service Life, 1993 and 2003

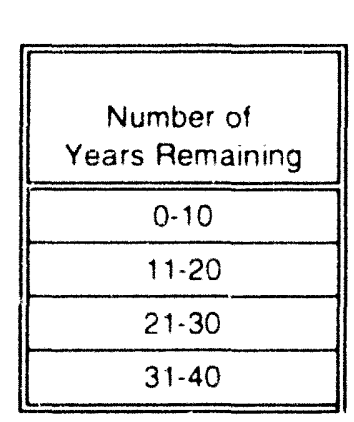

\begin{tabular}{|c|c|c|c|}
\hline $\begin{array}{l}\text { Number } \\
\text { of Units }\end{array}$ & $\begin{array}{c}\text { Avg. Life } \\
\text { Remaining } \\
(y r)\end{array}$ & $\begin{array}{c}\text { Avg. } \\
\text { Size } \\
(M W)\end{array}$ & $\begin{array}{c}\text { Avg. Repl. } \\
\text { Power Cost } \\
\left(\$ 10^{9}\right)\end{array}$ \\
\hline 1 & $\gamma$ & 67 & 0.1 \\
\hline 39 & 16 & 788 & 5.2 \\
\hline 36 & 23 & 877 & 8.9 \\
\hline 36 & 33 & 1090 & 168 \\
\hline
\end{tabular}

\begin{tabular}{|c|c|c|c|}
\hline $\begin{array}{c}\text { Number } \\
\text { of Units }\end{array}$ & $\begin{array}{c}\text { Avg. Life } \\
\text { Remaining } \\
(\mathrm{yr})\end{array}$ & $\begin{array}{c}\text { Avg. } \\
\text { Size } \\
(\mathrm{MW})\end{array}$ & $\begin{array}{c}\text { Avg. Repl. } \\
\text { Power Cost } \\
\left(\$ 10^{9}\right)\end{array}$ \\
\hline \hline 0 & - & - & - \\
\hline 39 & 6 & 738 & 1.0 \\
\hline 36 & 13 & 877 & 3.9 \\
\hline 36 & 23 & 1090 & 11.1 \\
\hline
\end{tabular}

TABLE A.5 Average Keplacement Power Cost for Reactors by Utility, 1993 and $2003^{a}$

\begin{tabular}{|c|}
\hline Utility Abbrv. \\
\hline ap \\
\hline aps \\
\hline be \\
\hline bge \\
\hline ce \\
\hline $\operatorname{cec}$ \\
\hline cei \\
\hline$c p$ \\
\hline $\mathrm{cpl}$ \\
\hline cyap \\
\hline de \\
\hline$d !$ \\
\hline$d p$ \\
\hline eo \\
\hline$t p$ \\
\hline$|p|$ \\
\hline$g p$ \\
\hline gou \\
\hline gsu \\
\hline hip \\
\hline ielp \\
\hline me \\
\hline ip \\
\hline myap \\
\hline
\end{tabular}

\begin{tabular}{|c|c|c|c|}
\hline \multicolumn{4}{|c|}{ Year 1993} \\
\hline $\begin{array}{l}\text { Number } \\
\text { of Units }\end{array}$ & $\begin{array}{c}\text { Avg. Life } \\
\text { Remaining } \\
(y r)\end{array}$ & $\begin{array}{l}\text { Avg } \\
\text { Size } \\
(\mathrm{MW})\end{array}$ & $\begin{array}{c}\text { Avg. Repl. } \\
\text { Power Cost } \\
\left(\$ 10^{9}\right)\end{array}$ \\
\hline 2 & 26 & 827 & 10.8 \\
\hline 3 & 32 & 1221 & 19.8 \\
\hline 1 & 19 & 670 & 7.1 \\
\hline 2 & 22 & 825 & 8.9 \\
\hline 12 & 23 & 974 & 12.2 \\
\hline 1 & 20 & 939 & 12.3 \\
\hline 1 & 33 & 1141 & 8.5 \\
\hline 2 & 11 & 399 & 2.0 \\
\hline 4 & 20 & 776 & 88 \\
\hline 1 & 14 & 565 & 2.9 \\
\hline 1 & 32 & 1055 & 12.4 \\
\hline 2 & 29 & 815 & 6.3 \\
\hline 7 & 26 & 1008 & 15.1 \\
\hline 4 & 25 & 978 & 8.0 \\
\hline 1 & 23 & 821 & 13.0 \\
\hline 4 & 20 & 753 & 10.5 \\
\hline 4 & 29 & 927 & 118 \\
\hline 2 & 18 & 714 & 5.8 \\
\hline 1 & 32 & 936 & 5.4 \\
\hline 2 & 35 & 1251 & 22.1 \\
\hline 1 & 17 & 538 & 1.2 \\
\hline 2 & 16 & 1040 & 27 \\
\hline 1 & 33 & 930 & 62 \\
\hline 1 & 15 & 830 & 66 \\
\hline
\end{tabular}

\begin{tabular}{|c|c|c|c|}
\hline $\begin{array}{l}\text { Number } \\
\text { of Units }\end{array}$ & $\begin{array}{c}\text { Avg. Life } \\
\text { Remaining } \\
(y r)\end{array}$ & $\begin{array}{c}\text { Avg. } \\
\text { Size } \\
\text { (MW) }\end{array}$ & $\begin{array}{c}\text { Avg. Repl. } \\
\text { Power Cost } \\
\left(\$ 10^{9}\right)\end{array}$ \\
\hline 2 & 16 & 827 & 5.8 \\
\hline 3 & 22 & 1221 & 13.2 \\
\hline 1 & 9 & 670 & 2.1 \\
\hline 2 & 12 & 825 & 3.5 \\
\hline 12 & 13 & 974 & 6.8 \\
\hline 1 & 10 & 939 & 4.4 \\
\hline 1 & 23 & 1141 & 4.9 \\
\hline 1 & 4 & 730 & 0.6 \\
\hline 4 & 10 & 776 & 4.0 \\
\hline 1 & 4 & 565 & 0.4 \\
\hline 1 & 22 & 1055 & 7.4 \\
\hline 2 & 19 & 815 & 3.3 \\
\hline 7 & 16 & 1008 & 8.7 \\
\hline 4 & 15 & 978 & 4.0 \\
\hline 1 & 13 & 821 & 5.7 \\
\hline 4 & 10 & 753 & 4.7 \\
\hline 4 & 19 & 927 & 7.3 \\
\hline 2 & 8 & 714 & 1.8 \\
\hline 1 & 22 & 936 & 2.6 \\
\hline 2 & 25 & 1251 & 157 \\
\hline 1 & 7 & 538 & 0.0 \\
\hline 2 & 6 & 1040 & 0.0 \\
\hline 1 & 23 & 930 & 35 \\
\hline 1 & 5 & 830 & 1.2 \\
\hline
\end{tabular}


TABLE A.5 (Cont.)

\begin{tabular}{|c|}
\hline Utility Abbr. \\
\hline nmp \\
\hline nppd \\
\hline nsp \\
\hline nu \\
\hline nypa \\
\hline oppd \\
\hline pe \\
\hline pge \\
\hline ppl \\
\hline pscnh \\
\hline pseg \\
\hline rge \\
\hline sce \\
\hline sceg \\
\hline te \\
\hline tue \\
\hline tva \\
\hline ue \\
\hline vp \\
\hline vynp \\
\hline wcno \\
\hline wep \\
\hline wpps \\
\hline wps \\
\hline
\end{tabular}

\begin{tabular}{|c|c|c|c|}
\hline $\begin{array}{l}\text { Number } \\
\text { of Units }\end{array}$ & $\begin{array}{c}\text { Avg. Life } \\
\text { Remaining } \\
(y r)\end{array}$ & $\begin{array}{l}\text { Avg. } \\
\text { Size } \\
(\mathrm{MW})\end{array}$ & $\begin{array}{c}\text { Avg. Repl. } \\
\text { Power Cost } \\
\left(\$ 10^{9}\right)\end{array}$ \\
\hline 2 & 23 & 853 & 13.8 \\
\hline 1 & 15 & 764 & 1.6 \\
\hline 3 & 19 & 533 & 2.1 \\
\hline 3 & 24 & 885 & 11.6 \\
\hline 2 & 19 & 874 & 10.4 \\
\hline 1 & 15 & 478 & 0.6 \\
\hline 4 & 24 & 1050 & 11.5 \\
\hline 1 & 18 & 1095 & 6.4 \\
\hline 2 & 30 & 1036 & 15.4 \\
\hline 1 & 33 & 1150 & 22.7 \\
\hline 3 & 21 & 1081 & 10.5 \\
\hline 1 & 13 & 470 & 3.5 \\
\hline 3 & 18 & 862 & 9.6 \\
\hline 1 & 29 & 885 & 14.3 \\
\hline 1 & 18 & 874 & 3.0 \\
\hline 2 & 38 & 1144 & 20.5 \\
\hline 6 & 26 & 1109 & 32 \\
\hline 1 & 31 & 1125 & 10.5 \\
\hline 4 & 23 & 846 & 11.3 \\
\hline 1 & 19 & 504 & 5.5 \\
\hline 1 & 32 & 1135 & 134 \\
\hline 2 & 19 & 485 & 52 \\
\hline 1 & 30 & 1095 & 12.8 \\
\hline 1 & 20 & 503 & 58 \\
\hline
\end{tabular}

Year 2003

\begin{tabular}{|c|c|c|c|}
\hline $\begin{array}{c}\text { Number } \\
\text { of Units }\end{array}$ & $\begin{array}{c}\text { Avg. Life } \\
\text { Remaining } \\
(\mathrm{yr})\end{array}$ & $\begin{array}{c}\text { Avg. } \\
\text { Size } \\
(\mathrm{MW})\end{array}$ & $\begin{array}{c}\text { Avg. Repl. } \\
\text { Power Cost } \\
\left(\$ 10^{9}\right)\end{array}$ \\
\hline 2 & 13 & 853 & 8.0 \\
\hline 1 & 5 & 764 & 0.0 \\
\hline 3 & 9 & 533 & 0.4 \\
\hline 3 & 14 & 885 & 5.9 \\
\hline 2 & 9 & 874 & 3.2 \\
\hline 1 & 5 & 478 & -0.1 \\
\hline 4 & 14 & 1050 & 6.3 \\
\hline 1 & 8 & 1095 & 1.7 \\
\hline 2 & 20 & 1036 & 9.0 \\
\hline 1 & 23 & 1150 & 15.1 \\
\hline 3 & 11 & 1081 & 4.8 \\
\hline 1 & 3 & 470 & 0.4 \\
\hline 3 & 8 & 862 & 3.2 \\
\hline 1 & 19 & 885 & 8.8 \\
\hline 1 & 8 & 874 & 0.3 \\
\hline 2 & 28 & 1144 & 15.4 \\
\hline 6 & 16 & 1109 & 1.0 \\
\hline 1 & 21 & 1125 & 6.0 \\
\hline 4 & 13 & 846 & 5.5 \\
\hline 1 & 9 & 504 & 1.7 \\
\hline 1 & 22 & 1135 & 8.0 \\
\hline 2 & 9 & 485 & 1.7 \\
\hline 1 & 20 & 1095 & 7.1 \\
\hline 1 & 10 & 503 & 2.2 \\
\hline
\end{tabular}

a Uilly abbreviations are listed in Table A.6. 
TABLE A.6 Utility Abbreviations Used in Table A.5

\begin{tabular}{|c|c|c|c|}
\hline Abbr. & Utility Name & Abbr. & Utility Name \\
\hline ap & Alabama Power Co. & gsu & Gulf States Utilities Co. \\
\hline aps & Arizona Public Service Co. & hlp & Houston Lighting and Power Co. \\
\hline be & Boston Edison Co. & ielp & lowa Electric Light and Power Co. \\
\hline bge & Baltimore Gas and Electric Co. & ime & Indiana and Michigan Electric Co. \\
\hline$c e$ & Commonwealth Edison Co. & ip & Illinois Power Co. \\
\hline $\operatorname{cec}$ & Consolidated Edison Co. & myap & Maine Yankee Atomic Power Co. \\
\hline cei & Cleveland Electric Illuminating Co. & $\mathrm{nmp}$ & Niagara Mohawk Power Corp. \\
\hline$c p$ & Consumers Power Co. & nppd & Nebraska Public Power District \\
\hline cpl & Carolina Power and Light Co. & nsp & Northern States Power Co. \\
\hline cyap & Connecticut Yankee Atomic Power Co. & nu & Northeast Utilities \\
\hline de & Detroit Edison Co. & nypa & New York Power Authority \\
\hline$d l$ & Duquesne Light Co. & oppd & Omaha Public Power District \\
\hline $\mathrm{dp}$ & Duke Power Co. & pe & Philadelphia Electric Co. \\
\hline eo & Entergy Operations, Inc. & pge & Portland General Electric Co. \\
\hline$f p$ & Florida Power Corp. & $\mathrm{ppl}$ & Pennsylvania Power and Light Co. \\
\hline $\mathrm{fpl}$ & Florida Power and Light Co. & pscnh & Public Service Co. of New Hampshire \\
\hline $\mathrm{gp}$ & Georgia Power Co. & pseg & Public Service Electric and Gas Co. \\
\hline gpu & GPU Nuclear Corp. & rge & Rochester Gas and Electric Corp. \\
\hline sce & Southern California E.dison Co. & vp & Virginia Power Co. \\
\hline sceg & South Carolina Electric and Gas Co. & vynp & Vermont Yankee Nuclear Power Corp. \\
\hline te & Toledo Edison Co. & weno & Wolf Creek Nuclear Op. Corp. \\
\hline tue & Texas Utilities Electric Co. & wep & Wisconsin Electric Power Co. \\
\hline tva & Tennessee Valley Authority & wpps & Washington Public Power Supply System \\
\hline ue & Union Electric Co. & wps & Wisconsin Public Service Corp. \\
\hline
\end{tabular}


TABLE A.7 Average Replacement Power Cost by Nuclear Steam System Suppliers and Design 'Types, 1993 and 2003

\begin{tabular}{|c|}
\hline Reactor Supplier \\
\hline 1 \\
\hline 2 \\
\hline 3 \\
\hline 4 \\
\hline 5 \\
\hline 6 \\
\hline $2 L P$ \\
\hline $3 L P$ \\
\hline $4 L P$ \\
\hline CE \\
\hline CE80 \\
\hline LLP \\
\hline
\end{tabular}

\begin{tabular}{|c|c|c|c||}
\hline $\begin{array}{c}\text { Number } \\
\text { of Units }\end{array}$ & $\begin{array}{c}\text { Avg. Life } \\
\text { Remaining } \\
(\mathrm{yr})\end{array}$ & $\begin{array}{c}\text { Avg } \\
\text { Size } \\
(\mathrm{MW})\end{array}$ & $\begin{array}{c}\text { Avg. Repl. } \\
\text { Power Cost } \\
\left(\$ 10^{9}\right)\end{array}$ \\
\hline 1 & 7 & 67 & 0.1 \\
\hline 2 & 14 & 618 & 3.4 \\
\hline 7 & 16 & 706 & 4.9 \\
\hline 19 & 23 & 907 & 8.5 \\
\hline 4 & 31 & 1064 & 17.4 \\
\hline 4 & 32 & 1037 & 6.5 \\
\hline 6 & 19 & 501 & 4.1 \\
\hline 14 & 23 & 775 & 9.2 \\
\hline 33 & 27 & 1092 & 13.3 \\
\hline 12 & 21 & 859 & 9.8 \\
\hline 3 & 32 & 1221 & 19.8 \\
\hline 7 & 21 & 840 & 8.2 \\
\hline
\end{tabular}

\begin{tabular}{||c|c|c|c||}
\hline $\begin{array}{c}\text { Number } \\
\text { of Units }\end{array}$ & $\begin{array}{c}\text { Avg. Life } \\
\text { Remaining } \\
(\mathrm{yr})\end{array}$ & $\begin{array}{c}\text { Avg. } \\
\text { Size } \\
(\mathrm{MW})\end{array}$ & $\begin{array}{c}\text { Avg. Repl. } \\
\text { Power Cost } \\
\left(\$ 10^{9}\right)\end{array}$ \\
\hline 0 & - & - & - \\
\hline 2 & 4 & 618 & 0.5 \\
\hline 7 & 6 & 706 & 1.1 \\
\hline 19 & 13 & 907 & 4.1 \\
\hline 4 & 21 & 1064 & 10.9 \\
\hline 4 & 22 & 1037 & 3.4 \\
\hline 6 & 9 & 501 & 1.2 \\
\hline 14 & 13 & 775 & 4.5 \\
\hline 33 & 17 & 1092 & 7.7 \\
\hline 12 & 11 & 859 & 4.3 \\
\hline 3 & 22 & 1221 & 13.2 \\
\hline 7 & 11 & 840 & 3.1 \\
\hline
\end{tabular}

$\begin{array}{ll}1 & \text { GE Type 1 } \\ 2 & \text { GE Type 2 } \\ 3 & \text { GE Type 3 } \\ 4 & \text { GE Type 4 }\end{array}$

$\begin{array}{ll}5 & \text { GE Type } 5 \\ 6 & \text { GE Type } 6 \\ \text { 2LP } & \text { Westinghouse Two-Loop } \\ \text { 3LP } & \text { Westinghouse Three-Loop }\end{array}$

4LP Westinghouse Four-Loop

CE Cornbustion Engineering

CE80 CE Standard Design

LLP B\&W Lowered Loop

TABLE A.8 Average Replacement Power Cost for Reactors by Turbine Generator Suppliers, 1993 and 2003

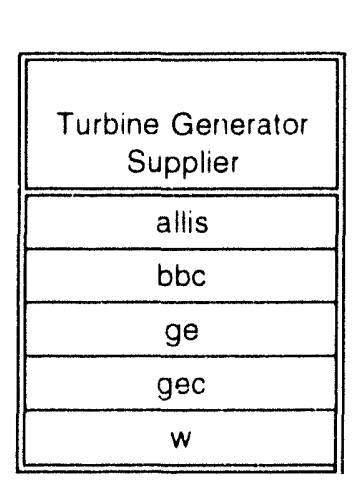

\begin{tabular}{|c|c|c|c|}
\hline $\begin{array}{l}\text { Number } \\
\text { of Units }\end{array}$ & $\begin{array}{c}\text { Avg. Life } \\
\text { Remaining } \\
(y r)\end{array}$ & $\begin{array}{l}\text { Avg. } \\
\text { Size } \\
(\mathrm{MW})\end{array}$ & $\begin{array}{l}\text { Avg. Repl. } \\
\text { Power Cost } \\
\left(\$ 10^{9}\right)\end{array}$ \\
\hline 3 & 35 & 1143 & 15.7 \\
\hline 1 & 16 & 1060 & 2.7 \\
\hline 58 & 23 & 910 & 9.8 \\
\hline 3 & 24 & 1068 & 12.7 \\
\hline 47 & 23 & 876 & 10.0 \\
\hline
\end{tabular}

\begin{tabular}{|c|c|c|c|}
\hline \multicolumn{4}{|c|}{ Year 2003} \\
\hline $\begin{array}{l}\text { Number } \\
\text { of Units }\end{array}$ & $\begin{array}{c}\text { Avg. Life } \\
\text { Remaining } \\
(y r)\end{array}$ & $\begin{array}{l}\text { Avg. } \\
\text { Size } \\
\text { (MW) }\end{array}$ & $\begin{array}{l}\text { Avg. Repl. } \\
\text { Power Cost } \\
\left(\$ 10^{9}\right)\end{array}$ \\
\hline 3 & 25 & 1143 & 11.1 \\
\hline 1 & 6 & 1060 & 0.0 \\
\hline 57 & 14 & 925 & 5.2 \\
\hline 3 & 14 & 1068 & 5.5 \\
\hline 47 & 13 & 876 & 5.0 \\
\hline
\end{tabular}

Allis Allis-Chalmers (U.S.)

bbc Brown Boveri et Cie. (Switzerland)

ge General Electric Co. (U.S.) gec General Electric Co. (U.K.)

w Westinghouse Electric Corp. (U.S.) 
TABLE A.9 Average Replacement Power Cost for Reactors by Architect Engineers, 1993 and 2003

\begin{tabular}{|c|}
\hline Architect Engineer \\
\hline aep \\
\hline bech \\
\hline br \\
\hline dbdb \\
\hline duke \\
\hline ebso \\
\hline flur \\
\hline gh \\
\hline ghdr \\
\hline gil \\
\hline niag \\
\hline pge \\
\hline pse \\
\hline pubs \\
\hline sbec \\
\hline sl \\
\hline ssi \\
\hline sw \\
\hline iva \\
\hline uec \\
\hline \\
\hline \\
\hline \\
\hline \\
\hline \\
\hline
\end{tabular}

\begin{tabular}{|c|c|c|c|}
\hline $\begin{array}{l}\text { Number } \\
\text { of Units }\end{array}$ & $\begin{array}{c}\text { Avg. Life } \\
\text { Remaining } \\
(y r)\end{array}$ & $\begin{array}{l}\text { Avg. } \\
\text { Size } \\
(\mathrm{MW})\end{array}$ & $\begin{array}{l}\text { Avg. Repl. } \\
\text { Power Cost } \\
\left(\$ 10^{9}\right)\end{array}$ \\
\hline 2 & 16 & 1040 & 2.7 \\
\hline 37 & 23 & 896 & 10.1 \\
\hline 3 & 20 & 826 & 6.0 \\
\hline 3 & 20 & 846 & 9.7 \\
\hline 4 & 31 & 1129 & 19.2 \\
\hline 7 & 24 & 777 & 11.6 \\
\hline 2 & 21 & 531 & 2.3 \\
\hline 1 & 37 & 1137 & 20.4 \\
\hline 1 & 15 & 478 & 0.6 \\
\hline 5 & 24 & 825 & 9.5 \\
\hline 1 & 12 & 615 & 3.4 \\
\hline 2 & 16 & 1080 & 11.4 \\
\hline 1 & 20 & 503 & 5.8 \\
\hline 2 & 15 & 1106 & 6.7 \\
\hline 2 & 35 & 1095 & 16.2 \\
\hline 14 & 25 & 976 & 11.8 \\
\hline 2 & 26 & 827 & 10.8 \\
\hline 12 & 25 & 863 & 10.7 \\
\hline 6 & 26 & 1109 & 3.2 \\
\hline 5 & 21 & 927 & 11.8 \\
\hline
\end{tabular}

\begin{tabular}{|c|c|c|c|}
\hline $\begin{array}{l}\text { Number } \\
\text { of Units }\end{array}$ & $\begin{array}{c}\text { Avg. Life } \\
\text { Remaining } \\
(y r)\end{array}$ & $\begin{array}{l}\text { Avg. } \\
\text { Size } \\
\text { (MW) }\end{array}$ & $\begin{array}{l}\text { Avg. Repl. } \\
\text { Power Cost } \\
\left(\$ 10^{9}\right)\end{array}$ \\
\hline 2 & 6 & 1040 & 0.0 \\
\hline 36 & 14 & 919 & 5.5 \\
\hline 3 & 10 & 826 & 2.6 \\
\hline 3 & 10 & 846 & 3.8 \\
\hline 4 & 21 & 1129 & 12.4 \\
\hline 7 & 14 & 777 & 6.2 \\
\hline 2 & 11 & 531 & 0.5 \\
\hline 1 & 27 & 1137 & 15.1 \\
\hline 1 & 5 & 478 & 0.1 \\
\hline 5 & 14 & 825 & 4.6 \\
\hline 1 & 2 & 615 & 0.3 \\
\hline 2 & 6 & 1080 & 2.7 \\
\hline 1 & 10 & 503 & 2.2 \\
\hline 2 & 5 & 1106 & 1.2 \\
\hline 2 & 25 & 1095 & 11.4 \\
\hline 14 & 15 & 976 & 6.6 \\
\hline 2 & 16 & 827 & 5.8 \\
\hline 12 & 15 & 863 & 5.5 \\
\hline 6 & 16 & 1109 & 1.0 \\
\hline 5 & 11 & 927 & 5.1 \\
\hline
\end{tabular}

aep American Electric Power

bech Bectel

br Burns \& Roe

$\mathrm{dbdb}$ Duke and Bechtel

duke Duke Power Company

ebso Ebasco

flur Fluor Pioneer gh ghdr gil

niag

pge

pse

pubs
Gibbs \& Hill

Gibbs \& Hill \& Durham \& Richardson Gilbert Associates

Niagara Mohawk Power Corporation

Pacific Gas \& Electric Company

Pioneer Services \& Engineering

Public Service Electric \& Gas Co. sbec sl ssi

sw

Iva

uec
Southern Services \& Bechtel Sargent \& Lundy Southern Services Stone \& Webster Tennessee Valley Authority United Engineering 
TABLE A.10 Average Replacement Power Cost for Reactors by Constructors, 1993 and 2003

\begin{tabular}{|c|}
\hline Constructor \\
\hline aep \\
\hline bald \\
\hline bech \\
\hline br \\
\hline brrt \\
\hline crve \\
\hline dani \\
\hline duke \\
\hline ebso \\
\hline ghdr \\
\hline gpc \\
\hline jones \\
\hline kais \\
\hline nsp \\
\hline pge \\
\hline pse \\
\hline sw \\
\hline tva \\
\hline vec \\
\hline wdco \\
\hline
\end{tabular}

aep American Electric Power

bald Baldwin Associates

bech Bechtel

br Bums \& Roe

brit Brown \& Root

cwe Commonwealth Edison Co

danı Damel International

\begin{tabular}{|c|c|c|c|}
\hline $\begin{array}{l}\text { Number } \\
\text { of Units }\end{array}$ & $\begin{array}{c}\text { Avg. Life } \\
\text { Remaining } \\
(y r)\end{array}$ & $\begin{array}{l}\text { Avg. } \\
\text { Size } \\
(\mathrm{MW}\rangle\end{array}$ & $\begin{array}{c}\text { Avg. Repl. } \\
\text { Power Cost } \\
\left(\$ 10^{9}\right)\end{array}$ \\
\hline 2 & 16 & 1040 & 2.7 \\
\hline 1 & 33 & 930 & 6.2 \\
\hline 33 & 22 & 852 & 9.0 \\
\hline 2 & 15 & 692 & 2.5 \\
\hline 4 & 28 & 967 & 13.8 \\
\hline 8 & 28 & 1075 & 15.7 \\
\hline 6 & 30 & 981 & 12.8 \\
\hline 7 & 26 & 1008 & 15.1 \\
\hline 8 & 25 & 885 & 13.7 \\
\hline 1 & 15 & 478 & 0.6 \\
\hline 4 & 29 & 927 & 11.8 \\
\hline 1 & 23 & 821 & 13.0 \\
\hline 1 & 33 & 1141 & 8.5 \\
\hline 2 & 21 & 531 & 2.3 \\
\hline 2 & 16 & 1080 & 11.4 \\
\hline 1 & 20 & 503 & 5.8 \\
\hline 13 & 24 & 844 & 10.1 \\
\hline 6 & 26 & 1109 & 3.? \\
\hline 8 & 18 & 907 & 8.1 \\
\hline 2 & 18 & 952 & 11.1 \\
\hline
\end{tabular}

duke Duke Power Company ebso Ebasco

ghat Gibos \& Hill \& Durham \& Richardson upc Georgla Power Company jones J A. Jones

káls Kaiser Engineers

nsp Northern States Power Company

\begin{tabular}{|c|c|c|c|}
\hline \multicolumn{4}{|c|}{ Year 2003} \\
\hline $\begin{array}{l}\text { Number } \\
\text { of Units }\end{array}$ & $\begin{array}{c}\text { Avg. Life } \\
\text { Remaining } \\
(y r)\end{array}$ & $\begin{array}{l}\text { Avg. } \\
\text { Size } \\
(\mathrm{MW})\end{array}$ & $\begin{array}{c}\text { Avg. Repl. } \\
\text { Power Cost } \\
\left(\$ 10^{9}\right)\end{array}$ \\
\hline 2 & 6 & 1040 & 0.0 \\
\hline 1 & 23 & 930 & 3.5 \\
\hline 32 & 12 & 876 & 4.5 \\
\hline 2 & 5 & 692 & 0.3 \\
\hline 4 & 18 & 967 & 8.6 \\
\hline 8 & 18 & 1075 & 9.7 \\
\hline 6 & 20 & 981 & 7.7 \\
\hline 7 & 16 & 1008 & 8.7 \\
\hline 8 & 15 & 885 & 7.9 \\
\hline 1 & 5 & 478 & 0.1 \\
\hline 4 & 19 & 927 & 7.3 \\
\hline 1 & 13 & 821 & 5.7 \\
\hline 1 & 23 & 1141 & 4.9 \\
\hline 2 & 11 & 531 & 0.5 \\
\hline 2 & 6 & 1080 & 2.7 \\
\hline 1 & 10 & 503 & 2.2 \\
\hline 13 & 14 & 844 & 5.1 \\
\hline 6 & 16 & 1109 & 1.0 \\
\hline 8 & 8 & 907 & 3.1 \\
\hline 2 & 8 & 952 & 3.3 \\
\hline
\end{tabular}

pge Pachic Gas \& Electric Co pse Ploneer Services \& Engmeenng sw Stone \& Webster

Iva Tennessee Valley Authority vec United Engmeering

wdco Westinghouse Development 


\section{Distribution for NUREG/CR-6080 (ANL-93/19)}

\section{Internal}
ANL Technical Publications Services
N. Clodi (5)
M. Clemmons
J. VanKuiken

\section{External}

U.S. Nuclear Regulatory Commission for distribution per 9C, 9D, GF Manager, U.S. Department of Energy Chicago Field Office ANL-E Libraries ANL-W Library

S. Feld, U.S. Nuclear Regulatory Commission 

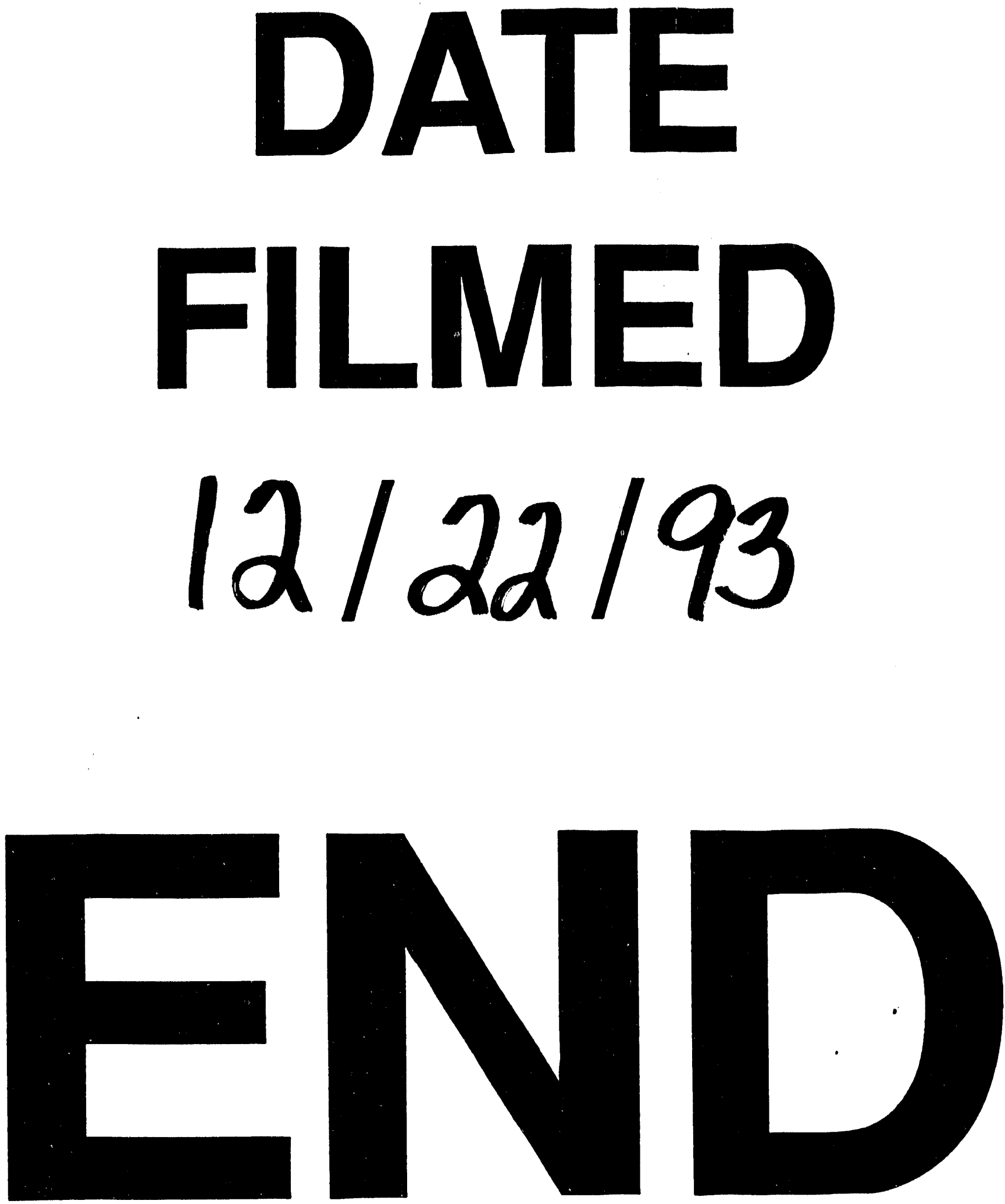
